\title{
Life Skill Development of Oklahoma 4-H Alumni
}

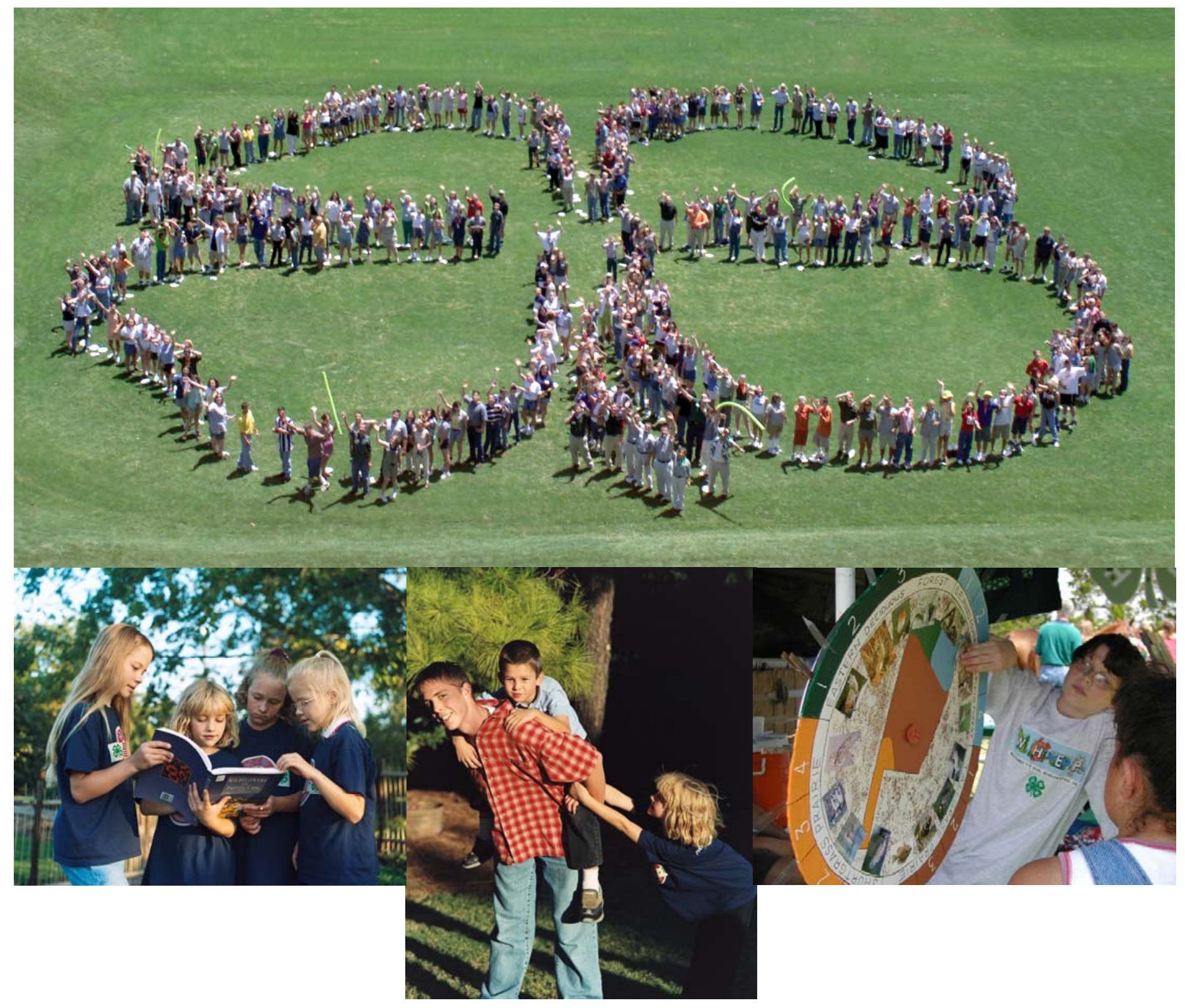

C. UNIVERSITY OF

IFAS EXTENSION

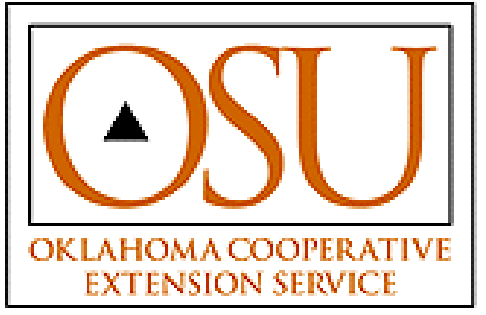




\section{Authors:}

Sarah E. Maass, M.S.

County Extension Agent, 4-H Youth Development

Kansas State Research and Extension

Lyon County

Carolyn S. Wilken, Ph.D., M.P.H.

Associate Professor

University of Florida

Joy Jordan, Ph.D.

Associate Professor

University of Florida

Gerald Culen, Ph.D.

Associate Professor

University of Florida

Nick Place, Ph.D.

Assistant Professor

University of Florida

\section{Special Thanks to:}

University of Florida: IFAS Extension, Department of

Family, Youth and Community Sciences and the Florida

4-H Program for the graduate assistantship, support, and encouragement of this research study.

Oklahoma Cooperative Extension Service and Oklahoma 4-H Foundation for the support, encouragement, and for all of the numerous resources that helped make this study possible.

The 232 Oklahoma 4-H Alumni who responded to this research study, thank you for your participation.

Todd Johnson for the pictures. 


\section{EXECUTIVE SUMMARY}

The purpose of this study was to assess the effect of long-term 4-H participation on the development of lifeskill competencies known to assist individuals with living a productive and rewarding life. Specific life skills assessed in this research included critical thinking, goal setting, communication, cooperation, conflict resolution, problem solving, decision making, and community service (Targeting Life Skills Model, n.d.).

This study surveyed Oklahoma 4-H alumni who had participated in the Oklahoma 4-H program at the highest levels (state and national) between the years 1969 and 1998. Respondents included former State 4-H Officers, State 4-H Scholarship winners, and National 4-H Congress attendees.

Four hundred forty-four (444) surveys yielded 223 valid responses for a response rate of $57 \%$. Almost $90 \%$ of respondents identified themselves as Caucasian, and $10.5 \%$ as Native American; nearly $62 \%$ of the respondents identified themselves as rural (living on a farm while participating in $4-\mathrm{H}$ ); and $67.3 \%$ were female, $32.7 \%$ male. More than $90 \%$ had completed some education beyond high school.

\section{METHODOLOGY}

Life skills were measured using the Life Skills Inventory (Maass, 2004). The survey included items from the Indiana 4-H Impact Study (McKinley, 1999A), the National 4-H Impact Study (Ladewig \& Thomas, 1987), the Targeting Life Skills Model (n.d.), and public speaking (Seevers and Dormody, 1994, 1995; Ward, 1996).

A cross-sectional, quasi-experimental research design with a mailed survey, was used to identify which factors Oklahoma 4-H programs highest achieving alumni identified as most influential in impacting their adult lives. Independent variables were measured in the following areas:

- 4-H experiences;

- influential aspects of $4-\mathrm{H}$;

- participation in other youth organizations;

- life skill development attained through participation in 4-H and other youth organizations;

- current community involvement; and

- demographics.
"The organization taught me how to 'sell' myself and gave me the confidence to do what is right 'no matter what.' The public speaking project/experience placed me head and shoulders above my college classmates."

Noble County 4-H Alum, Cohort 2

\section{SAMPLE}

Alumni who participated in one or more of the following activities between the years of 1969 and 1998 were included in the population of this study:

- National 4-H Congress;

- National 4-H Conference;

- Oklahoma 4-H Key Club;

- State officer;

- District officer;
- State 4-H ambassador;

- State Hall of Fame winner;

- State project winner; and

- State scholarship winner.

The mailing yielded 223 valid surveys for a response rate of $57 \%$. A demographic summary of the sample is reported in Table 1. For the initial analysis, respondents were categorized by cohort based upon the years of 4-H participation: Cohort 1 (ages 21 to 33 participating in 4-H during 1989 through 1998), Cohort 2 (ages 34 to 43 participating in 4-H during 1979 through 1988), and Cohort 3 (ages 44 to 53 participating 
in 4-H during 1969 through 1978). Although the cohorts were equivalent in size (37\%, $36 \%$ and $27 \%$ respectively) no demographic differences were seen between cohorts.

The average age of respondents was 37.5 years $(S D=8.43$ years). More than $90 \%$ of the respondents had participated in $4-\mathrm{H}$ for 8 years or more (range 4 to 10 years; $\bar{x}=9.08$; SD $=1.057$ ). As expected, the majority of respondents had held multiple 4-H offices at the local, county, and state levels and had participated in 4-H activities, events, and competitions from the local to the national levels.

The participants were asked if they were currently or if they had ever been an adult 4-H volunteer. Fortyfive percent $(45 \%)$ of the $4-\mathrm{H}$ alumni reported being a $4-\mathrm{H}$ volunteer at some point in time. Forty-six percent $(46 \%)$ served as a club/organizational leader, $39 \%$ served as a project leader, and $51 \%$ were committee members.

Table 1. Sociodemographic Characteristics of Sample*

\begin{tabular}{|c|c|c|}
\hline & $\mathrm{n}$ & $\%$ \\
\hline \multicolumn{3}{|l|}{ Gender } \\
\hline Male & 72 & 32.7 \\
\hline Female & 148 & 67.3 \\
\hline \multicolumn{3}{|l|}{ Ethnicity } \\
\hline White, not of Hispanic Origin & 198 & 89.6 \\
\hline American Indian or Alaskan Native & 23 & 10.4 \\
\hline \multicolumn{3}{|l|}{ Education Level } \\
\hline GED/High School & 3 & 1.4 \\
\hline Technical School & 4 & 1.8 \\
\hline Some College & 28 & 12.6 \\
\hline Associate Degree & 11 & 5.0 \\
\hline Bachelor Degree & 102 & 45.9 \\
\hline Master Degree & 61 & 27.5 \\
\hline Doctorate Degree & 13 & 5.9 \\
\hline \multicolumn{3}{|l|}{ Residence while in 4-H } \\
\hline Farm & 134 & 61.5 \\
\hline Rural, non-farm & 34 & 15.6 \\
\hline$<5,000$ & 23 & 10.6 \\
\hline $5,000-20,000$ & 13 & 6.0 \\
\hline$>20,000$ & 14 & 6.4 \\
\hline
\end{tabular}

*Total number in each category varies from 218-221 due to missing data

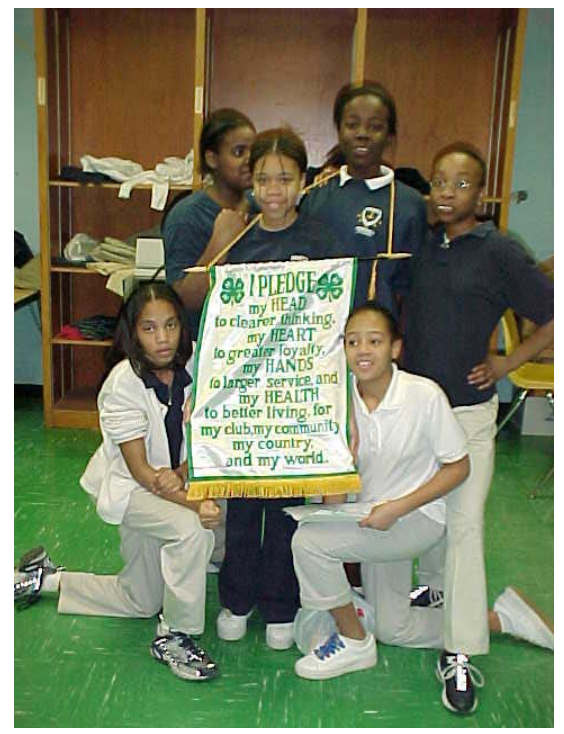

"Often I just thought I was working to complete a project or get ready for an event, but in doing so I learned more about myself and the world around me. Before long it became habit for me to do things a certain way, and I took that into adulthood."

Comanche County 4-H Alum, Cohort 1

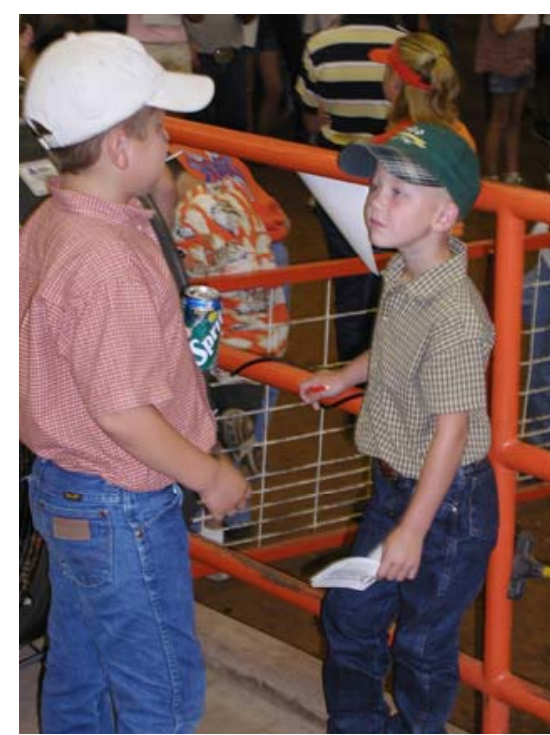

Life Skill Development of Oklahoma 4-H Alumni 


\section{FINDINGS}

Participants were asked to reflect on their 4-H experience and to recall specific aspects of the 4- $\mathrm{H}$ program that had the most influence on their adult life, opportunities to grow, and future career decisions. Results of the analyses are described below.

\section{Most Influential Aspects}

Table 2 details the list of key aspects of the 4-H program and the respondents' ratings of how much each aspect influenced their everyday lives. In summary, respondents identified "4-H trips" and "4-H projects" as the aspects of $4-\mathrm{H}$ that had the most influence on their everyday lives. The majority of the sample $(64.2 \%)$ felt that $4-\mathrm{H}$ projects influenced their everyday lives a great deal $(\overline{\times}=4.53 ; S D=0.70)$. More than half of the sample $(57.2 \%)$ rated "adult $4-\mathrm{H}$ volunteers and leaders" as having a great deal of influence on everyday lives $(\overline{\times}=4.45 ; S D=0.77)$.

Table 2. Most Influential Aspects of 4-H

\begin{tabular}{lcccc}
\hline \multicolumn{1}{c}{ 4-H Aspects } & $\mathrm{n}$ & $\overline{\times}$ & SD & Rank \\
\hline 4-H trips & 219 & 4.54 & 0.73 & 1 \\
4-H projects & 218 & 4.53 & 0.70 & 2 \\
Opportunities to compete in 4-H & 216 & 4.53 & 0.67 & 2 \\
Adult 4-H leaders & 215 & 4.45 & 0.77 & 4 \\
Other 4-H members & 218 & 4.02 & 0.86 & 5 \\
Awards and prizes received & 217 & 3.97 & 0.92 & 6 \\
4-H club meetings & 219 & 3.95 & 0.91 & 7 \\
\hline
\end{tabular}

On a Likert Scale $5=$ a great deal to $1=$ not at all

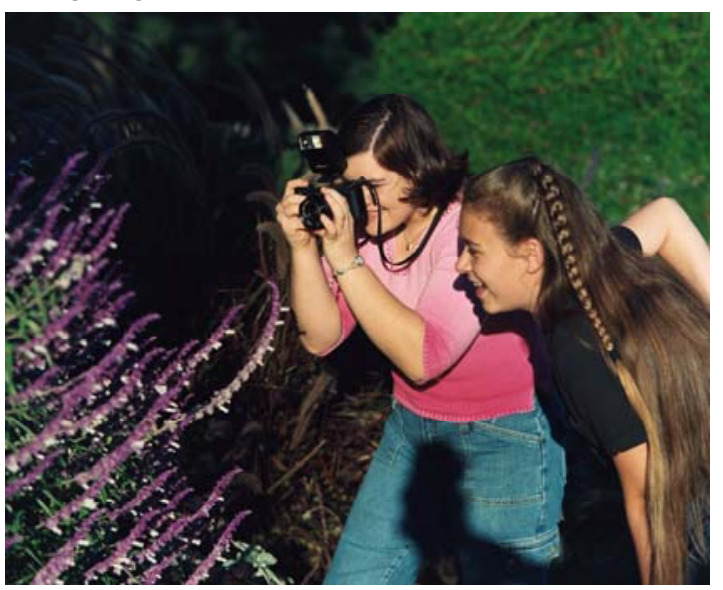

\section{Opportunities to Grow and Learn}

Another series of questions asked 4-H members how often they felt they had been given opportunities to grow and develop. The top 6 responses were:

1. Given an opportunity to lead others

2. Able to make a contribution

3. Given freedom to develop and use own skills

4. Involved in planning club activities

5. Given challenging tasks

6. Included in making important decisions

Note:

\section{Involvement in Other Youth Organizations}

"4-H gave me a great background with dealing with people of all different backgrounds, managing teams, and the basis of an organization. Everything I have been involved in with 4- $\mathrm{H}$ helped give a backbone to everything I have accomplished."

Garfield County 4-H Alum, Cohort 1
Nearly all $(92.6 \%$, or $n=206)$ reported that they had been a member of another youth organization in addition to $4-\mathrm{H}$ for more than one year. In addition to $4-\mathrm{H}$, the majority had also been involved in religious youth groups, athletics, school leadership (i.e., student council), and vocational training organizations (i.e., Future Homemakers of America and Future Farmers of America).

\section{Life Skill Development}

The dependent variable in this study was life skill development. The Life Skill Inventory (LSI) created for this study used the 35 life skills identified by Hendricks (1998) plus a variable assessing public speaking (Seevers and Dormody, 1994, 1995; Ward, 1996). Participants were asked to 
determine to what extent 4- $\mathrm{H}$ and another youth organization, in which they participated for more than one year, taught them life skills. Participants were asked to complete the same question while reflecting on the life skills learned in the 4-H program and the other youth organization. Table 3 displays the mean, standard deviation, and rank for each of the 36 life skills taught by the 4-H Program and by Other Youth Organizations.

Table 3. Development of Life Skills Taught by the 4-H Program \& Other Youth Organizations $(n=223)$

\begin{tabular}{|c|c|c|c|c|c|c|}
\hline \multirow{2}{*}{ Life Skill } & \multicolumn{3}{|c|}{ 4-H Program } & \multicolumn{3}{|c|}{ Other Organizations } \\
\hline & $\bar{x}$ & SD & Rank & $\bar{x}$ & SD & Rank \\
\hline Public Speaking & 4.79 & 0.56 & 1 & 3.16 & 1.27 & 33 \\
\hline Community Service Volunteering & 4.65 & 0.65 & 2 & 3.77 & 1.20 & 24 \\
\hline Self-discipline & 4.58 & 0.70 & 3 & 4.24 & 0.93 & 2 \\
\hline Self-responsibility & 4.58 & 0.67 & 3 & 4.11 & 0.97 & 6 \\
\hline Teamwork & 4.58 & 0.69 & 3 & 4.01 & 1.00 & 10 \\
\hline Cooperation & 4.57 & 0.60 & 6 & 4.15 & 0.89 & 4 \\
\hline Marketable Skills & 4.56 & 0.75 & 7 & 3.77 & 1.16 & 24 \\
\hline Self-esteem & 4.55 & 0.66 & 8 & 4.00 & 1.01 & 13 \\
\hline Social Skills & 4.53 & 0.66 & 9 & 4.13 & 0.93 & 5 \\
\hline Responsible Citizenship & 4.52 & 0.64 & 10 & 4.01 & 1.03 & 10 \\
\hline Self-motivation & 4.52 & 0.74 & 10 & 3.96 & 1.07 & 15 \\
\hline Contributions to Group Effort & 4.47 & 0.71 & 12 & 4.03 & 0.90 & 7 \\
\hline Wise Use of Resources & 4.46 & 0.72 & 13 & 3.78 & 1.05 & 23 \\
\hline Keeping Records & 4.44 & 0.78 & 14 & 2.62 & 1.30 & 35 \\
\hline Sharing & 4.44 & 0.73 & 14 & 3.98 & 1.02 & 14 \\
\hline Leadership & 4.43 & 0.71 & 16 & 3.49 & 1.23 & 29 \\
\hline Goal Setting & 4.39 & 0.79 & 17 & 3.87 & 1.05 & 20 \\
\hline Communication & 4.39 & 0.77 & 17 & 3.53 & 1.01 & 28 \\
\hline Learning to Learn & 4.28 & 0.91 & 19 & 3.24 & 1.19 & 32 \\
\hline Problem Solving & 4.24 & 0.75 & 20 & 3.88 & 0.98 & 19 \\
\hline Service Learning & 4.24 & 0.83 & 20 & 3.58 & 1.10 & 27 \\
\hline Character & 4.22 & 0.80 & 22 & 4.42 & 0.82 & 1 \\
\hline Planning/Organizing & 4.20 & 0.83 & 23 & 3.35 & 1.17 & 30 \\
\hline Accepting Differences & 4.14 & 0.88 & 24 & 4.23 & 0.88 & 3 \\
\hline Critical Thinking & 4.12 & 0.87 & 25 & 3.59 & 1.05 & 26 \\
\hline Concern for Others & 4.12 & 0.85 & 25 & 4.03 & 1.12 & 7 \\
\hline Nurturing Relationships & 4.02 & 0.89 & 27 & 3.96 & 1.02 & 15 \\
\hline Resiliency & 3.96 & 0.98 & 28 & 4.01 & 1.10 & 10 \\
\hline Decision Making & 3.83 & 1.02 & 29 & 3.34 & 1.17 & 31 \\
\hline Managing Feelings & 3.82 & 1.00 & 30 & 3.79 & 1.10 & 22 \\
\hline Empathy & 3.79 & 0.98 & 31 & 3.90 & 1.02 & 18 \\
\hline Stress Management & 3.77 & 1.02 & 32 & 4.03 & 1.02 & 7 \\
\hline Healthy Lifestyle Choices & 3.76 & 1.21 & 33 & 2.57 & 1.32 & 36 \\
\hline Conflict Resolution & 3.73 & 0.98 & 34 & 3.87 & 1.07 & 20 \\
\hline Personal Safety & 3.73 & 1.15 & 34 & 3.93 & 1.22 & 17 \\
\hline Disease Prevention & 3.09 & 1.34 & 36 & 2.82 & 1.35 & 34 \\
\hline
\end{tabular}

Note: On a Likert Scale $5=$ a great deal to $1=$ not at all 
A summed score on the LSI was created for the 36 life skills for 4-H and Other Youth Organizations, respectively. Paired t-tests were used to compare respondents' 4-H LSI score with each respondent's "Other Youth Organizations LSI Score." Results of this analysis suggest significantly higher attribution of life skill development to $4-\mathrm{H}$ than to the secondary youth development organization $(d=18.01 ; \mathrm{t}=9.925, d f=193$; $\mathrm{p}<.000)$.

\section{What Impacts Life Skill Development?}

The primary question put forth in this study was "What aspects of the Oklahoma 4-H program are perceived to

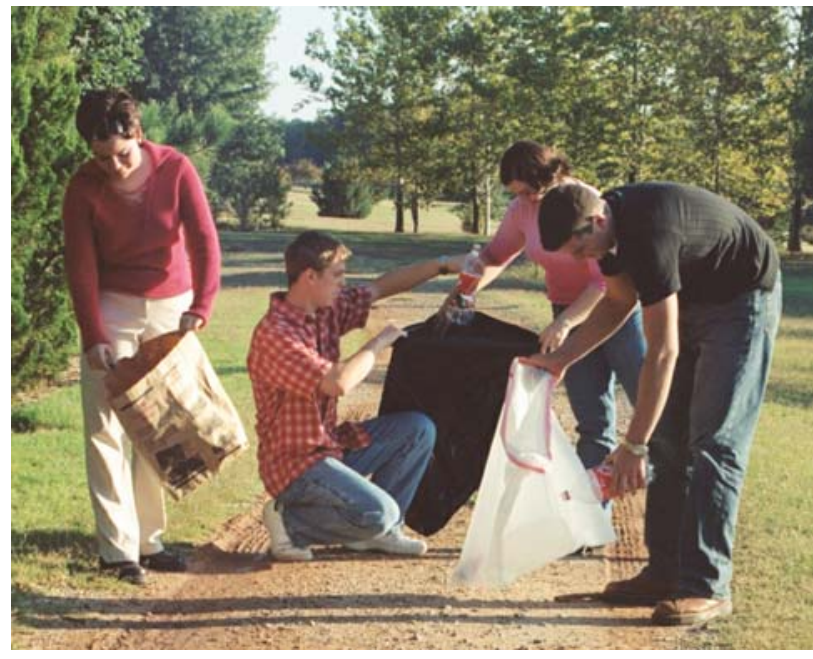
have made a difference in the lives of its alumni?" Multiple regression analyses were used to determine which personal factors and various aspects of the $4-\mathrm{H}$ program would most reliably predict differences in respondents' 4-H LSI Score.

The following independent variables were used to these analyses.

- 4-H experiences;

- influential aspects of 4-H;

- participation in other youth organizations;

- life skill development attained through participation in 4-H and other youth organizations;

- current community involvement; and

- demographics.

"4-H has made me a better person. I like challenges and it gave me the opportunity to see different places and things and to be involved with all different kinds of people. I have met and maintained several life long friendships."

Osage County 4-H Alum, Cohort 2

Levels of offices held and 4-H participation were established using a weighted scoring system which gave more weight to higher offices and participation. The Total Offices Held Adjusted Score had a range of 1 , respondent held one local office, to 27, where the respondent held several offices at different levels $(\bar{x}=8.15 ; S D=5.53)$. Adjusted $4-\mathrm{H}$ Participation Score ranged from a minimum of 7 to a maximum of $129(\bar{x}=70.9$; $S D=26.17)$. More than $90 \%$ of the respondents participated in $4-\mathrm{H}$ for 8 years or more. It was also found that $4-\mathrm{H}$ alumni are more likely to credit the 4-H program with their life skill development than to other youth organizations (đ $=18.01 ; \mathrm{t}=9.925 ; d f=193 ; \mathrm{p}<.000)$.

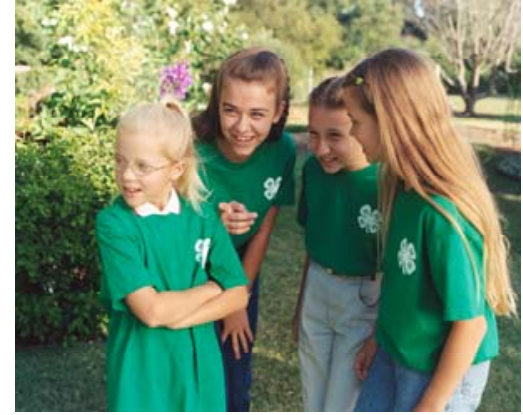

Results of the statistical analysis identified seven variables that predicted the variance in the LSI Score:

- freedom to develop and use own skills;

- adult 4-H volunteers and leaders;

- 4-H trips;

- life skills learned in other youth organizations;

- being included in making important decisions;

- 4-H club meetings; and

- other aspects of 4-H.

Figure 1 displays the variables that predicted the variance in the LSI score among the respondents. Freedom to develop and use skills was the largest identified variable, making up $29 \%$ of the predicted variance. Adult leaders followed with $16 \%$. Other variables in this study that predicted the Life Skill Development of Oklahoma 4-H Alumni
4-H gave me the opportunity to learn and deal with different life cultures and how to handle different life styles.

Stephens County Alum, Cohort 2 
variance of the Life Skills Inventory Score were: $4-\mathrm{H}$ trips, $7 \%$; other organizations, $6 \%$; making important decisions, $3 \%$; and $4-\mathrm{H}$ club meetings, $1 \%$. The remaining $38 \%$ of the variance is made up of other aspects of $4-\mathrm{H}$. For example, parliamentary procedure, service learning, and learning from other cultures may have contributed to the $38 \%$ that is not identified.

Figure 1. Aspects Predictive of the Variance in Life Skills Inventory Score of Total Sample

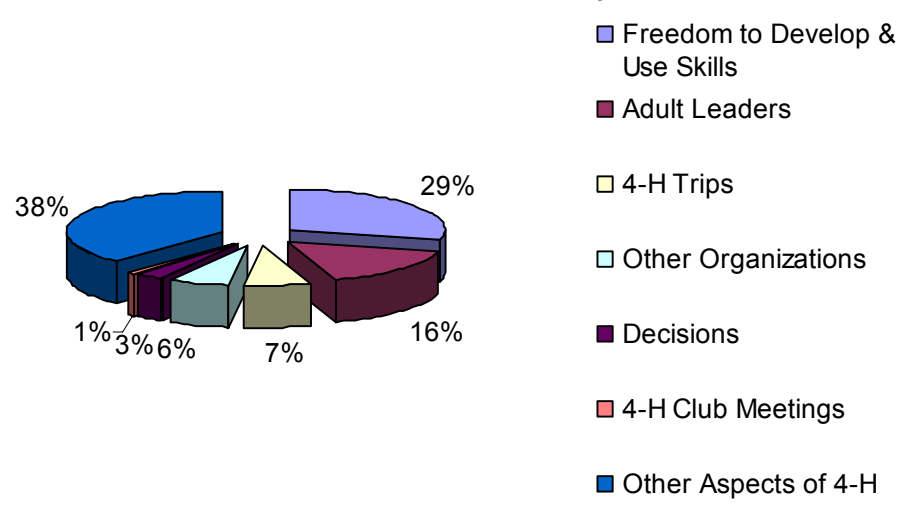

In order to provide the most detailed information possible to $4-\mathrm{H}$ administrators and program planners, a series of models, controlling for gender and cohort, were developed and are reported in Figures 2 and 3.

\begin{tabular}{|l|}
\hline ". . . my 4-H experience was \\
extremely beneficial in preparing for \\
many of the challenges of life. I am \\
confident that I had a great advantage \\
in many adult leadership experiences \\
because of 4-H. I continue to use \\
many of the skills that were nurtured \\
by 4-H activities. 4-H was by far the \\
most important aspect of my youth, \\
except that of my family." \\
Muskogee County 4-H Alum, Cohort 3
\end{tabular}

Important differences were observed between males and females in the factors that contribute to the variance in the 4-H LSI scores (see Figure 2). For example "freedom to develop and use skills" accounted for $43 \%$ of the variance for males, yet only $3 \%$ for females. " $4-\mathrm{H}$ trips" were more predictive of the variance for females $(15 \%)$ than males $(12 \%)$. "4-H club meetings" were predictive of life skill scores for males (11\%), but was not as explicit for females. For females (7\%), "Other Youth Organizations LSI Score" was predictive of life skills, but was not explicit for males. "Adult 4-H leaders and volunteers" were more influential according to the males $(6 \%)$ than for the females (4\%). While these differences are interesting, it is not clear if they are statistically significant.

Figure 2. Aspects Predictive of the Variance in Life Skills Inventory Score by Gender

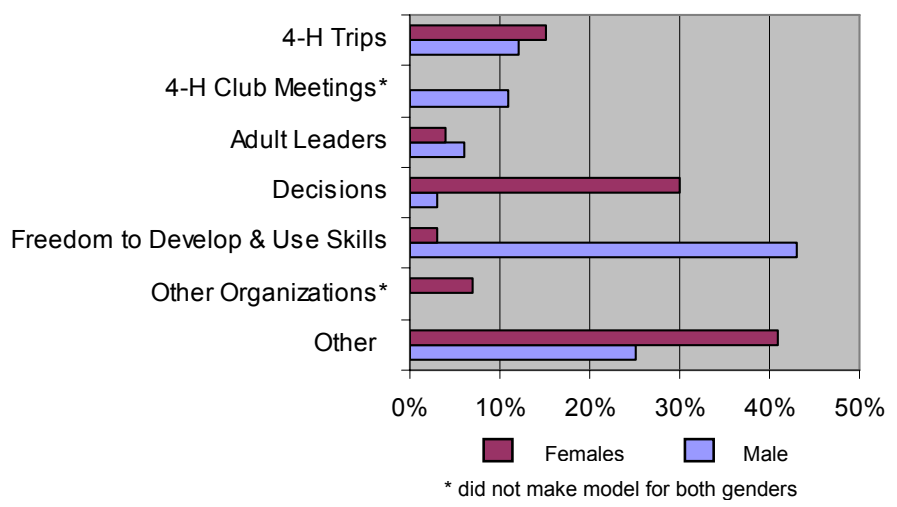


"4-H trips," "adult 4-H volunteers and leaders," "included in making important decisions," and "Other Youth Organization LSI Score" contributed to the development of the LSI Score in all three cohorts (see Figure 3). "4-H trips" were more predictive of the variance for cohort 1 $(34 \%)$ than both cohort $2(3 \%)$ and cohort $3(8 \%)$. "Adult $4-\mathrm{H}$ volunteers and leaders" were more predictive of the variance for cohort $2(34 \%)$ than both cohort $1(6 \%)$ and cohort $3(13 \%)$. "Included in making important decisions" were more predictive of the variance for cohort 3 $(40 \%)$ than both cohort $1(9 \%)$ and cohort $2(18 \%)$. The variance accounted for by "Other Youth Organization LSI Score" was comparable between cohort $1(6 \%)$, cohort $2(5 \%)$, and cohort $3(6 \%)$.

"Freedom to develop and use skills" did not account for any variance in cohort 2, but did account for variance in cohort 1 (5\%) and cohort 3 (5\%). "4-H club meetings" did not account for variance in any of the cohorts.

"4-H definitely made an impact on the development of my life skills. I know what a great program 4- $\mathrm{H}$ is to our youth and that is why I chose to come back and be an adult volunteer. Through 4-H I learned the importance of setting goals and even how to deal with the hardships when you don't achieve them."

Tulsa County 4-H Alum, Cohort 1

Figure 3. Aspects Predictive of the Variance in Life Skills Inventory Score by Cohorts

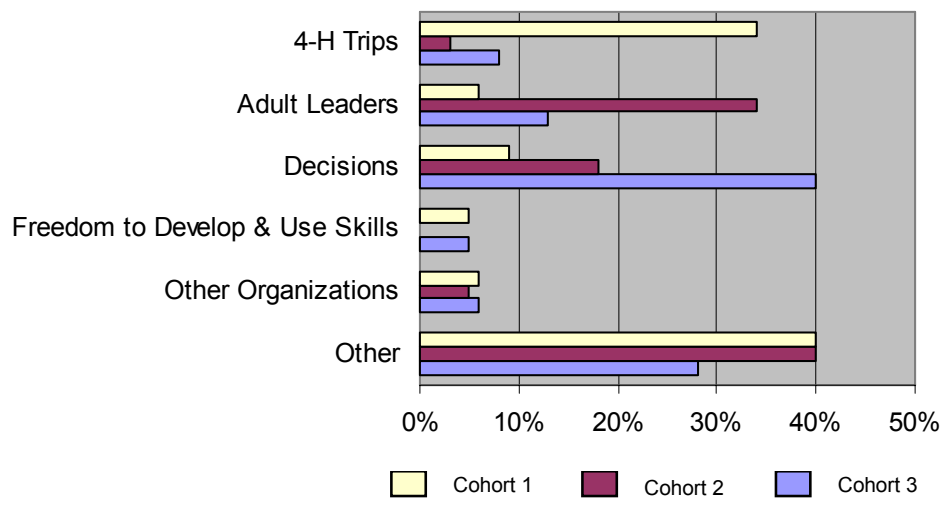

\section{SUMMARY}

The purpose of this study was to assess the effect of long-term 4-H participation on the development of lifeskill competencies known to assist individuals with living a productive and rewarding life. This study had a response rate of $57 \%$. It is of interest to note that of the respondents, $10.5 \%$ were identified as Native American. This is interesting because of the Native American population in Oklahoma. When asked about education more than $90 \%$ had completed some education beyond high school. Therefore, it can be concluded that with the sample of Oklahoma 4-H alumni that there is a link between a high level of $4-\mathrm{H}$ participation and the level of education achieved.

"4-H also taught me to always do my best and work hard at whatever I do. This work ethic has carried over to college and my career helping me keep good grades and promotions in the work force. I consider 4-H the most influential activity in my life."

Caddo County 4-H Alum, Cohort 1

The 4- $\mathrm{H}$ aspects found to be the most influential in the Oklahoma 4- $\mathrm{H}$ program were: 4- $\mathrm{H}$ trips, 4- $\mathrm{H}$ club meetings, and adult $4-\mathrm{H}$ volunteers and leaders. These findings were consistent with what McKinley (1999B) found with the Indiana 4-H Alumni. Forty-five percent (45\%) of the respondents in this study reported serving as a 4- $\mathrm{H}$ volunteer at some point in time. Oklahoma 4-H alumni reported being more involved in volunteering with the 4-H organization, than similar studies (McKinley 1999A; 1999B; and Ladewig \& Thomas, 1987).

This research study found that the opportunities that 4-H'ers are given throughout their 4-H membership, such as making decisions and developing and utilizing their own skills, influence their development of life 
skills. Contrary to these findings, Mustian (1988) found that both 4-H alumni and participants in other organizations rated the opportunity to make a contribution and to develop skills higher than leadership opportunities, planning activities, making decisions, and challenging tasks.

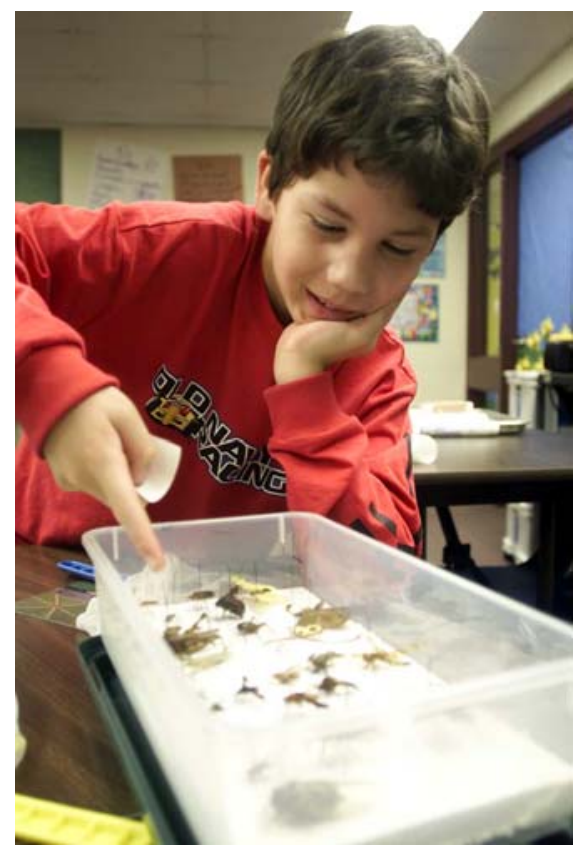

Participation in various 4- $\mathrm{H}$ trips such as National 4- $\mathrm{H}$ Congress, $4-\mathrm{H}$ Round-Up, and Denver Western Round-Up contribute to the Life Skills Inventory Score of 4-H members. As a 4-H member grows and develops in project areas, they learn various life skills that build on one another. 4H'ers take what they have learned in one project area and have the ability to apply it to another project area. According to Haskell (2001), "the aim of all education ... . is to apply what we learn in different contexts, and to recognize and extend that learning to completely new situations" (p. 3). 4-H members learn life skills, directly and indirectly, throughout the tenure of their membership. These life skills have the potential to be transferred from a project area, to the county fair, from experiences at 4- $\mathrm{H}$ trips, or holding a state $4-\mathrm{H}$ office. This is the transfer of learning theory as it applies to the $4-\mathrm{H}$ program. Almost all learning requires a transfer of learning from a previous situation to a new or current situation.

Many aspects and opportunities offered through the Oklahoma 4-H program make a difference in the life skill development of its members. Four-H'ers should be empowered to participate and contribute in club meetings and 4- $\mathrm{H}$ trips, and be actively involved in making important decisions that affect themselves and the club or activity that they are involved in. It is important that 4H'ers have a say in what their club is going to do for the community service projects and what fundraising activities will be planned for the year. Older 4-H members whose cognitive skills are more highly developed should be more involved in these decisions. This gives the 4-H'er an opportunity to use past learning experiences and apply these experiences to a new aspect of learning. This is when the transfer of learning takes place.

Based on these findings, parents, volunteer leaders, and the county and state staff should strongly encourage participation in 4-H activities as a way to encourage the development of life skills. These activities allow the 4-H'ers to grow, meet new people, and not only experience new things, but experience them on different levels. The 4-H organization offers these opportunities to youth and therefore members should be informed and encouraged to take advantage of these opportunities whenever they are given the chance.

Four-H alone cannot teach all the life skills one needs. The life skills that are learned and enhanced by the participation in other youth organizations also contribute to the variance of the 4-H Life Skills Inventory Score. In addition to other youth organizations, freedom to develop and use skills and being included in making important decisions, and the following life skills: public speaking, self-confidence, leadership skills, basic living skills, responsibility, community appreciation, goal setting, management, social skills, keeping records, working in teams, and dealing with people of different backgrounds, were also found to be important in explaining the variance in the 4-H life skills, therefore contributing to the life skill development.

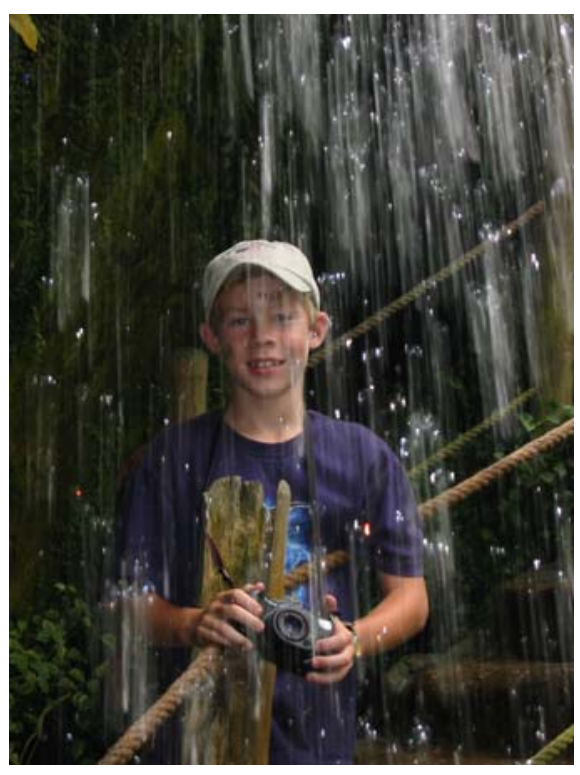




\section{References:}

Haskell, R.E. (2001). Transfer of learning: Cognition, instruction, and reasoning. San Diego, California: Academic Press.

Hendricks, P.A. (1998). Developing youth curriculum using the targeting life skills model. lowa State University.

Ladewig, H. \& Thomas, J.K. (1987). Assessing the impact of 4-H on former members. The Texas A\&M University System.

Maass, S. E. (2004). A study of life skill development of Oklahoma 4-H alumni during the years of 4-H participation 1969-1998. Unpublished master's thesis, University of Florida, Gainesville, Florida.

McKinley, S.K. (1999A). 4-H alumni perceptions regarding the impact of the Indiana 4-H program. Unpublished doctorial dissertation, Purdue University, West Lafayette, Indiana.

McKinley, S.K. (1999B, October). 4-H alumni perceptions regarding the impact of the Indiana 4-H program. Paper presented at the meeting of the National Association of Extension 4-H Agents, Pittsburgh, PA.

Mustian, R.D. (1988). Impact study, 4-H: Assessing the impact of 4-H on former members in North Carolina. Raleigh, NC: North Carolina Agricultural Extension Service, North Carolina State University.

Seevers, B.S., \& Dormody, T.J. (1994). 4-H youth participation in leadership development activities: A tristate study. Journal of Agricultural Education, 35(4), 49-54.

Seevers, B.S. \& Dormody, T.J. (1995). Leadership life skills development: Perceptions of senior 4-H youth. Journal of Extension 33(4). Retrieved from http://www.joe.org/joe/1995august/rb1.html

Targeting Life Skills Model, lowa State University Extension. (n.d.). Retrieved September 24, 2002, from http://www.extension.iastate.edu/4H/lifeskills/previewwheel.html

Ward, C.K. (1996). Life skill development related to participation in 4-H animal science projects. Journal of Extension 34(2). Retrieved May 28, 2002, from http://www.joe.org/joe/1996april/rb2.html 